\title{
ON THE POSSIBLE EXISTENCE OF SUPERSTRONG MAGNETIC FIELDS IN A LIMB SOLAR FLARE
}

\author{
I. I. Yakovkin, V.G. Lozitsky \\ Astronomical Observatory of the Taras Shevchenko National University \\ of Kyiv, Kyiv, Ukraine,yakovkinii@gmail.com, lozitsky_v@ukr.net
}

\begin{abstract}
We present the simultaneous observations of the K Ca II $3933.7 \AA, \mathrm{H} \delta 4101.7 \AA$ and He I $4471.5 \AA$ lines in the limb solar flare of July 17 , 1981. For two moments of the flare we analyzed Stokes $I \pm V$ and $V$ profiles of these lines from observations made on the Echelle spectrograph of the horizontal solar telescope of the Astronomical Observatory of Taras Shevchenko National University of Kiev. In the flash phase of the flare, all named lines had very wide emissions, with a wing length of 6-8 $\AA$. An interesting feature was observed in the violet wings of these lines, namely, narrow emission peaks with a width of only $0.25-$ $0.35 \AA$. The Zeeman splitting of these emission peaks correspond to magnetic field strength in range 1300-2900 $\mathrm{G}$ at altitudes of $10-15 \mathrm{Mm}$ above the level of the photosphere. Magnetic fields of 'kilogauss' range (up to $3200 \mathrm{G}$ ) were found for some locations also in post-peak phase of the flare. Likely, the true local magnetic fields in the flare could be even larger, since the obtained results represent a longitudinal component of the magnetic field assuming that the filling factor equals unity. A new indication of the existence of superstrong magnetic fields follows from a comparison of the kinetic temperatures and turbulent velocities found from the narrow emission component in the flash phase of the flare. Considering this emission component to be optically thin, we found that there is an anti-correlation between temperature and turbulent velocity. Such a dependence seems unlikely and, possibly, the widths of the line profiles reflect, in our case, not turbulent velocities, but very strong magnetic fields. The corresponding estimates of the magnetic field by the $\mathrm{K}$ Ca II line lead to the value $B=8.3 \mathrm{kG}$, and by the He I 4471.5 line - to the value $B=6.7 \mathrm{kG}$. Considering that the He I line is clearly closer to the case of an optically thin layer, the closeness of these estimates is very encouraging. Our results are apparently the first indications of superstrong magnetic fields of 6-7 kG at an altitude of about $10 \mathrm{Mm}$ in a solar flare.
\end{abstract}

Keywords: Sun, solar activity, solar flares, magnetic fields, spectral lines, the Zeeman effect, temperatures, turbulent velocities, superstrong magnetic fields.

АНОТАЦІЯ. Представлено результати одночасних спостережень ліній К Са II 3933,7 А, Н $\delta 4101,7 \AA$ i Не I 4471,5 А у лімбовому сонячному спалаху 17 липня 1981 року. Для двох моментів спалаху були проаналізовані стоксові профілі $I \pm V$ та $V$ цих ліній на основі спостережень, проведених на ешельному спектрографі горизонтального сонячного телескопа Астрономічної обсерваторії Київського національного університету імені Тараса Шевченка. У флаш-фазі спалаху всі названі лінії мали дуже широкі емісії 3 довжиною крил 6-8 А. Цікава особливість спостерігалась у фіолетових крилах цих ліній, а саме вузькі емісійні піки 3 шириною лише 0,25-0,35 $\AA$. Земанівське розщеплення цих емісійних піків відповідає напруженостям магнітного поля в діапазоні 1300-2900 Гс і висотам 10-15 Мм над рівнем фотосфери. Магнітні поля діапазону «кілогауссового» (до 3200 Гс) були знайдені у деяких місцях також в інший момент, що відповідає фазі після максимуму спалаху. Ймовірно, дійсні локальні магнітні поля у спалаху можуть бути ще більшими, оскільки отримані результати представляють собою поздовжню складову магнітного поля, вважаючи, що коефіцієнт заповнення дорівнює одиниці. Нове свідчення існування надсильних магнітних полів випливає 3 порівняння кінетичних температур і турбулентних швидкостей, знайдених по вузькій емісійній компоненті у флашфазі спалаху. Вважаючи цей компонент оптично тонким, ми виявили, що існує антикореляція між температурою та турбулентною швидкістю. Така залежність уявляється малоймовірною, i, можливо, ширина лінійних профілів відображає, у нашому випадку, не турбулентні швидкості, а дуже сильні магнітні поля. Відповідні оцінки магнітного поля по лінії К Са II дають величину $B=8,3$ кГс, а по лінії Не I 4471,5 - величину $B=6,7$ кГс. Враховуючи, що лінія Не I явно ближче до випадку оптично тонкого шару, близькість цих оцінок дуже обнадійлива. Отримані нами результати, можливо, $\epsilon$ першими свідченнями надсильних магнітних полів рівня 6-7 кГс на висоті близько 10 Мм у сонячній спалаху.

Ключові слова: Сонце, сонячна активність, сонячні спалахи, магнітні поля, спектральні лінії, ефект Зеємана, температури, турбулентні швидкості, надсильні магнітні поля.

\section{Introduction}

At present, there are very little data in the literature about magnetic fields in limb solar flares. The first such measurements were made by Koval (1977) using the $\mathrm{H} \alpha$ 
line. It was found that the magnitude of the magnetic field, measured by the relative splitting of the line in orthogonal circular polarizations (i.e., in the $I+V$ and $I-V$ spectra, where $I$ and $V$ are the corresponding Stokes parameters), is typically several hundred gauss $(\mathrm{G})$. However, a case of a rather significant relative displacement of the $I \pm V$ profiles corresponding to a magnetic field of $9000 \mathrm{G}$ was also detected. Named author had the following point of view: "However, such large values are unlikely in the light of existing ideas about the structure of magnetic fields in the solar atmosphere". It should be noted that even magnetic fields of $\sim 10^{2} \mathrm{G}$ are 'too strong' for limb flares. Indeed, if the magnetic field tube is homogeneous and non-twisted, then the upper limit of $B_{\max }$ in the tube can be estimated from the simple condition of the equality of the magnetic pressure $B^{2} / 8 \pi$ inside the tube and the gas pressure $P=n k T$ outside the tube. Limb solar flares occur in the chromosphere and lower corona, where the gas pressure in undisturbed atmosphere is $\sim 10^{-1} \div 10^{2} \mathrm{dyn} / \mathrm{cm}^{2}$. However, at such pressure, $B_{\max }$ should be in range $1 \div 50$ $\mathrm{G}$, which is at least an order of magnitude less than observed. Furthermore, given that observations with a circular polarization analyzer give a mainly longitudinal component of the magnetic field, the magnitude of the magnetic field may be even larger. As it was pointed above, such strong magnetic fields, maybe, can occur in strongly twisted magnetic structures like force-free ropes.

The magnetic fields of $200 \mathrm{G}$ were measured using the $\mathrm{H} \alpha$ line also in the limb solar flare of $M 7.7$ class of 2012 July 19 (Kirichek et al., 2013). The results obtained refer to a rather high altitude above the limb, about $40 \mathrm{Mm}$. In this case, a significant lack of parallelism of the bisectors of $I \pm V$ profiles was observed too, with a maximum of their splitting at a distance of $0.4 \AA$ from the center of the emission profile. In the named paper, a theoretical MHD force-free model was proposed that allows explain the existence of such strong fields in the corona due to the strong twisting of the power lines. According to numerical estimations in frame of the model, the magnetic field strength increases by about 2 orders in comparison with the weak external field of 1-2 G level which is typical for the solar corona.

Recently, Kuridze et al. (2019) reported on the unique observation of flaring coronal loops at the solar limb using high-resolution imaging spectropolarimetry in $\mathrm{Ca}$ II $8542 \AA$ line from the Swedish $1 \mathrm{~m}$ Solar Telescope. They found magnetic field strengths as high as $350 \mathrm{G}$ at heights up to $25 \mathrm{Mm}$ above the solar limb. As to field order, these measurements are similar to above-named data by Kirichek et al (2013).

\section{Observations}

The solar flare of 1981 July 17 occurred on the eastern limb of the Sun, in the vicinity of the place with coordinates $7^{\circ} \mathrm{S}, 90^{\circ} \mathrm{E}$. According to the bulletin "Solnechnyie Dannyie" (1981), the flare was associated with the active region № 325, which appeared on the Sun's disk the next day, 1981 July 18.

This flare was observed with the Echelle spectrograph of the horizontal solar telescope of the Astronomical
Observatory of Taras Shevchenko National University of Kyiv (Lozitsky, 2016), starting from about $8^{\mathrm{h}} 15^{\mathrm{m}}$ UT. Observers were N.I. Lozitska, V.G. Lozitsky and P.M. Polupan. The flare emission was observed initially in a spectrohelioscope, which allows observe the entire "royal" (near the equatorial) zone of the Sun's disk in light of the $\mathrm{H} \alpha$ line. Natalia Lozitska, identifying the flare position in white light at the entrance slit of the Echelle spectrograph, noticed an interesting detail: this flare was visible for some time also in white light as a small arched feature on Sun's limb. As we know from the literature, limb solar flares were no longer observed in the white light. It should be noted that in order for such observational manifestations to be possible, the optical thickness in the continuum $\tau_{\mathrm{c}}$ must be close to unity. Since $\tau_{\mathrm{c}} \approx n_{\mathrm{H}} L$, where $n_{\mathrm{H}}$ is the concentration of neutral hydrogen atoms, $L$ is the effective linear length of the flare, the condition $\tau_{\mathrm{c}} \approx 1$ can be fulfilled even when the plasma density is less than photospheric one $\left(\sim 10^{15} \mathrm{~cm}^{-3}\right)$. If for the flare the effective length is written through $L_{\mathrm{fl}}$ and for the photosphere through $L_{\mathrm{ph}}$, then we can expect that $L_{\mathrm{fl}} / L_{\mathrm{ph}}=10-100$. This means that to observe a limb flare in white light, it is sufficient that $n_{\mathrm{H}} \sim 10^{13} \div 10^{14} \mathrm{~cm}^{-3}$.

According to our estimation, the optical flare class was $2 B$, which is higher than by bulletin "Solnechnyie Dannyie" (SB). However, we did not perform the exact measurements of the flare area required to strictly determine its class. The main value of our observations is that a wide spectrum interval, from 3800 to $6600 \AA$, was recorded simultaneously where bright and interesting emissions of hydrogen, helium, and ionized calcium lines were observed. Another advantage of our observations is that $I+V$ and $I-V$ spectra were obtained simultaneously, on separate adjacent bands of the spectrum (see Fig. 1 below). This was made thanks to the fact that the circular polarization analyzer was composed on a base of a $\lambda / 4$ plate in front of the entrance slit of the spectrograph and a two-beams splitting prism (analogous to the Wollaston prism) behind the entrance slit. Therefore, $I+V$ and $I-V$ spectra relate to the same moment of time and to the same places on the Sun.

The flare spectrum was photographed on WP1 ORWO photo-plates with exposures of $10 \div 30$ sec. In the $8^{\mathrm{h}} 17^{\mathrm{m}} \div$ $9^{\mathrm{h}} 51^{\mathrm{m}}$ UT time interval, six exposures were made. Below, the first Zeeman spectrogram obtained in $8^{\mathrm{h}} 17^{\mathrm{m}}$ UT with exposure of $10 \mathrm{sec}$ is analyzed. This time corresponds, apparently, to the flash phase of the flare that is evident due to the very wide wings of the spectral lines (Fig. 1).

\section{Line profiles}

A visual inspection of the $8^{\mathrm{h}} 17^{\mathrm{m}}$ spectrogram shown that it contains bright emissions of about ten lines of hydrogen, helium and $\mathrm{Ca}$ II. In this study we present results obtained from the K Ca II $3933.7 \AA, \mathrm{H} \delta 4101.7 \AA$ and He I $4471.5 \AA$ lines.

For flash phase of the flare, $8^{\mathrm{h}} 17^{\mathrm{m}}$, the shape of the K Ca II $3933.7 \AA$ and He I $4471.5 \AA$ lines clearly indicates that there were at least two emission components in these lines: wide and narrow, 1.8-2 $\AA$ apart in 


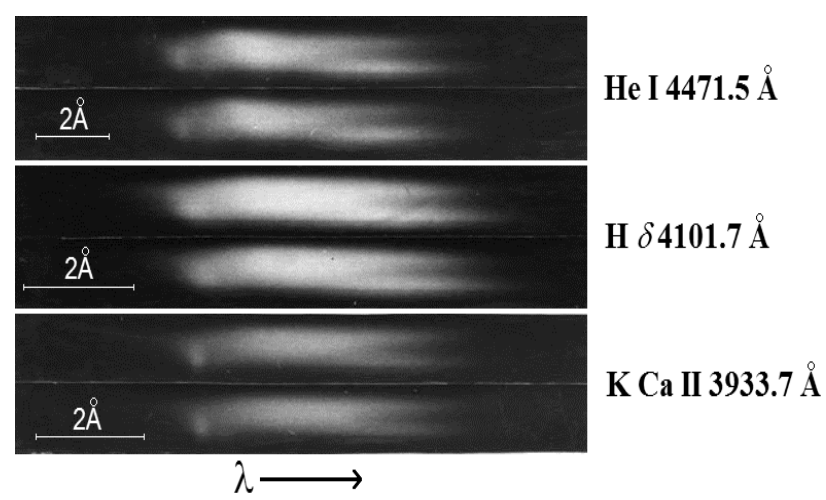

Figure 1: Positive images of the He I 4471.5, $\mathrm{H} \delta 4101.7$ and K Ca II 3933.7 lines on the spectrogram for $8^{\mathrm{h}} 17^{\mathrm{m}}$ UT. Each line is represented by two images that correspond to the $I+V$ and $I-V$ spectra. The width of each stripe corresponds to approximately 32 arc sec or 23 Mm on the Sun.

wavelength (Fig. 1). It can be seen from this Figure that the total widths of the emission lines of $\mathrm{K} \mathrm{Ca}$ II and $\mathrm{H} \delta$ are almost the same. This directly indicates that nonthermal mechanisms play the main role in the expansion of lines. In case if the profiles of these lines were expanded only by temperature, the width of the $\mathrm{K}$ line would be approximately 6.5 times narrower than the hydrogen line.

16 minutes after the flash phase, at $8^{\mathrm{h}} 33^{\mathrm{m}}$, the emissions in the spectral lines were divided into several discrete components corresponding to relative radial velocities up to $170 \mathrm{~km} / \mathrm{s}$. The narrow component of the emission has disappeared till this moment; it was not visible even in the $\mathrm{H}$ and $\mathrm{K} \mathrm{Ca}$ II lines. At least 3 separate emission components are present in the lines under study. These emissions correspond to the heights of up to $20 \mathrm{Mm}$ above the level of photosphere

A detailed study of the profiles of these lines was carried out in two ways: by the traditional method using an МФ-4 microdensitometer and using an Epson Perfection V 550 scanner, which allows obtain twodimensional scans of images recorded on transparent films or on photo-plates. In the first case, in order to convert the density into intensity, it is necessary to take into account the characteristic curve of the photographic material as well as the scattered light on the photographic plate. In the second case, it is necessary to take into account two characteristic curves, namely, the curve of the photoemulsion and the curve of the scanner itself. Both curves are nonlinear and require preliminary determination by special methods. In order to do this, we used a step attenuator, for which transmittances are precisely known. As a result, we could compare the data obtained with the microdensitometer and the scanner, and it turned out that these data are very well consistent with each other.

For $8^{\mathrm{h}} 17^{\mathrm{m}}$, the photometric line profiles clearly show the presence of a discrete narrow component in the 'violet' wing of the observed profiles (Fig. 2). This is most clearly seen in the K Ca II line, where this effect can be traced for about $10 \mathrm{Mm}$ in the direction of the entrance slit, i.e. by flare height.

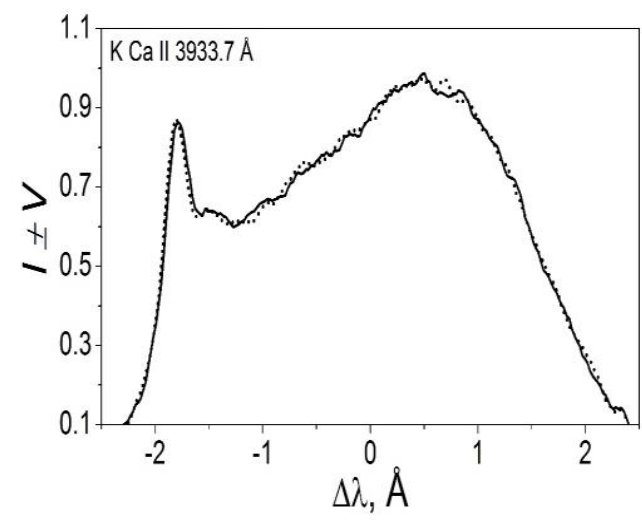

Figure 2: The $I \pm V$ profiles of the $\mathrm{K} \mathrm{Ca}$ II line in the studied flare for $8^{\mathrm{h}} 17^{\mathrm{m}}$ observed at a height of about 12 $\mathrm{Mm}$ above photosphere. One can see the presence of a narrow component in the 'violet' wing of the flare emission (at $\Delta \lambda \approx-1.8 \AA$ ).

\section{Magnetic fields}

We used various methods to measure magnetic field in the flare. In particular, we estimated the longitudinal component to the line of sight, $B_{\mathrm{LOS}}$, using weak-field approximation, when

$$
V=(\partial I / \partial \lambda) \Delta \lambda_{H}
$$

where $V$ and $I$ are Stokes parameters, $\partial I / \partial \lambda$ is Stokes $I$ gradient in a spectral line, $\Delta \lambda_{\mathrm{H}}$ is its Zeeman splitting. For example, for K Ca II $3933.7 \AA$ line (which has effective Lande factors geff $=1.167$ )

$$
B_{\mathrm{LOS}}=B \cos \gamma=1.186 \cdot 10^{5} \times[V /(\partial I / \partial \lambda)]
$$

where magnetic field strength $B_{\mathrm{LOS}}$ is expressed in gauss (G), and wavelength $\lambda$ - in $\AA$. In practice, we determined the Stokes $V$ amplitude, $V_{\max }$, and compared one with corresponding parameter of $(\partial I / \partial \lambda)_{\max }$.

For flash phase of the flare, we measured magnetic field also by Zeeman splitting of the narrow component after extraction this component in the explicit form and its approximation by Gaussian. In this case, we fixed shift of the 'center of gravity' of these Gaussian in $I+V$ and $I-V$ spectra. For after-peak phase $\left(8^{\mathrm{h}} 33^{\mathrm{m}}\right)$, the Zeeman splitting was measured by wide profiles of lines. In order to reduce the noise-like fluctuations in wings of profiles, only those portions of the line profiles were taken into account that directly adjoined its apex and corresponding to the upper half of its maximum intensity.

It was found that for $8^{\mathrm{h}} 17^{\mathrm{m}}$ magnetic field strengths in the flare were in range $1300-2900 \mathrm{G}$ at altitudes of 10-15 Mm above the level of the photosphere. Magnetic fields of 'kilogauss' range (up to $3200 \mathrm{G}$ ) were found for some locations also in post-peak phase of the flare $\left(8^{\mathrm{h}} 33^{\mathrm{m}}\right)$. The typical errors of our measurements are, as rule, $\pm 150 \mathrm{G}$. 


\section{Temperatures and turbulent velocities}

In order to determine the temperature $T$ and the turbulent velocity $\xi_{\text {turb }}$ in the flare, only narrow component of emission was analyzed (Figs. 1 and 2). For this purpose, it was necessary to extract this component in its pure form, without superposing on the wide component. In order to separate the narrow component from the wide one, we approximated the wide component by the most acceptable Gaussian profiles. Moreover, since we could not approximate the entire wide component with a Gaussian distribution, we chose the most suitable Gaussian profile only for those sections of the wide component that were directly adjacent to the narrow component. In fact, these were sections in the range from -3 to $-1 \AA$ in Fig. 2.

We found that shape of extracted narrow component was close to the Gaussian distribution. This circumstance, likely, means that approximation of the optically thin layer is suitable. In this case, we can determine the temperature $T$ and the turbulent velocity $\xi_{\text {turb }}$ using well-known simple formula:

$$
\Delta \lambda_{D}=\left(\lambda_{0} / \mathrm{c}\right) \times\left(2 k T / m+\xi_{\text {turb }}^{2}\right)^{1 / 2},
$$

where $\Delta \lambda_{\mathrm{D}}$ is Doppler widths, $\lambda_{0}$ is the unperturbed wavelength of the spectral line, $c$ is the speed of light, $k$ is the Boltzmann constant, $m$ is the mass of the atom.

Results of comparison of $\xi_{\text {turb }}$ vs. $T$ are presented on Fig. 3. One can see well visible tendency to anticorrelation of these parameters.

This seems strange because, based on general considerations, we can expect that turbulent velocities should also increase with increasing temperature in the plasma. This leads us to suspect that the additional (compared to temperature) broadening of the line profiles is actually caused not by turbulent velocities, but by strong magnetic fields of mixed polarity.

The corresponding estimates of the magnetic field were made in assumption, that turbulent velocities should be the same for different temperatures. Likely, this leads us to some

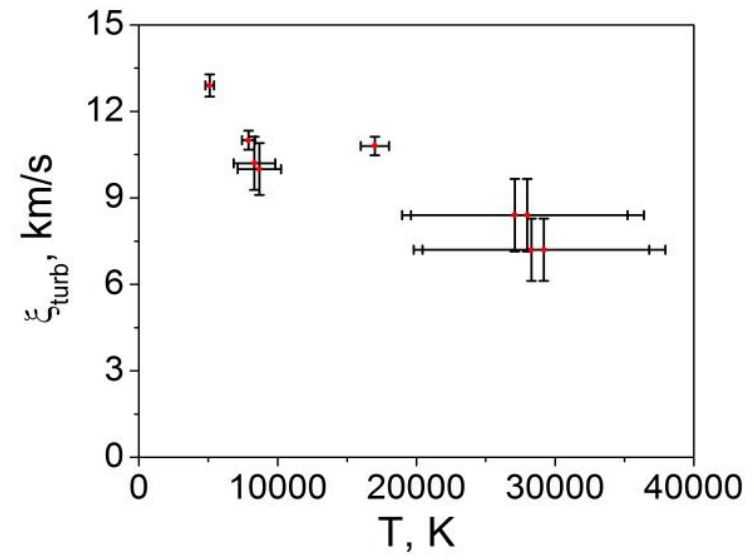

Figure 3: Comparison of temperatures and turbulent velocities in the explosive phase of the flare, found from the widths of the narrow component of the emission. lover estimation of the mixed polarity magnetic fields. For this case we found $B=8.3 \mathrm{kG}$ by the $\mathrm{K} \mathrm{Ca}$ II line and $B=$ $6.7 \mathrm{kG}$ by the He I 4471.5 line. Considering that the He I line is clearly closer to the case of an optically thin layer, the closeness of these estimates is very encouraging. Our results are apparently the first indications of superstrong magnetic fields of 6-7 kG at an altitude of about $10 \mathrm{Mm}$ in a solar flare.

\section{Conclusion and Discussion}

The main conclusion of our work is that in the limb solar flare of July 17, 1981, there were very strong magnetic fields up to about $3 \mathrm{kG}$ in two moments: in its explosive phase and 16 min after it. Such magnetic fields were observed at altitudes of 10-18 Mm, i.e. in lower solar corona. It is important to note that true local magnetic fields in the flare could be even larger, since the obtained results represent a longitudinal component of the magnetic field assuming that the filling factor equals unity.

Another interesting feature of the flare is that very narrow emissions were observed in the $\mathrm{K} \mathrm{Ca} \mathrm{II} \mathrm{and} \mathrm{He} \mathrm{I}$ lines against the background of broad emission typical of the explosive phase of the flare. If we consider these emissions to be optically thin, then we get an anticorrelation of temperatures and turbulent velocities. Physically, this is unlikely and may reflect the expansion of the line profiles not by turbulent velocities, but by very strong magnetic fields of mixed polarity. This assumption allows to obtain a estimation of the mixed polarity magnetic fields, namely, $B=8.3 \mathrm{kG}$ by the $\mathrm{K} \mathrm{Ca}$ II line and $B=6.7$ $\mathrm{kG}$ by the He I 4471.5 line. It is also possible that in other flares the assumed turbulent expansion of the profiles is actually magnetic expansion. For example, a very local in height increase in turbulence in a powerful flare on October 28, 2003 (Lozitsky et al., 2017) could be caused, in fact, due to very strong 'entangled' magnetic fields.

Acknowledgements. This study was funded by the Taras Shevchenko National University of Kyiv, project No. 19БФ023-03.

\section{References}

Byull. Solnech. Dannye Akad. Nauk USSR: 1981, No.7.

Kirichek E.A., Solov'ev A.A., Lozitskaya N.I., Lozitskii V.G.: 2013, Geomagn. \& Aeronomy, 53, 831.

Koval A.N.: 1977, Bull. Crimean Astrophys. Obs., 57, 133.

Kuridze D., Mathioudakis M., Morgan H., Oliver R. et al.: 2019, Astrophys. J., 874, art. id. 126, 12 pp.

Lozitsky V.G., Yakovkin I.I., Lozitska N.I.: 2020, Journ. Phys. Studies, 24, No. 2, id.2901 (6p.).

Lozitsky V.G.: 2016, Adv. Space Res., 57, 398.

Lozitsky V.G., Baranovsky E.A., Lozitska N.I., Tarashchuk V.P.: 2017, Journ. Phys. Studies, 21, No. 3, id 3902 (7 p.) 